\title{
Camping as empowerment strategy: a report of experience in palliative care
}

\begin{abstract}
Take care of adolescents with cancer in the process of death and dying is a challenge for both family and professionals that surround them, because of the high emotional cost and characteristics that mark this phase of human development. The objective of this study was to verify if the camp was an efficient resource of empowerment to strengthen the autonomy and self-confidence of adolescents and children with cancer diagnosis, providing to all an intense exchange of experiences capable of changing the course of treatment. A total of 30 children and adolescents diagnosed with cancer and treated at the outpatient clinic of a hospital in the city of São Paulo and 29 companions during the period of April 2013. From the observation of a multidisciplinary team, it was noticed that the camp made possible young people deal differently with the limitations imposed by the disease, because the environment allowed a group interaction that awakened the ability to become involved, affect and be affected by the other. The empowerment achieved during the camp showed that this is an effective resource for palliative care, able to re-establish links and strengthen patients to cope with their illnesses.
\end{abstract}

Keywords: acampamento, câncer, cuidados paliativos, pediatrics, empowerment
Volume I Issue 7 - 2017

\author{
Karla Fabiana Begosso Sampaio da Fonseca \\ Carbonari, Paula Vincenzi Gaiolla, Daniele \\ Soares Carlin, Maria Luiza Alessi Ribeiro, \\ Hígor Sampaio da Fonseca, Carolina Zavatini \\ Pereira, Suzana Helena Martins Mesquita, \\ Maria Aparecida Oliveira, Cecília Maria Lima \\ da Costa, Mágna Rosiane Teixeira, Elis Regina \\ Varalda Rodrigues, Aline Andruskevicius de \\ Castro \\ Clínica São Luckas, Brazil
}

Correspondence: Karla Fabiana Begosso Sampaio da Fonseca Carbonari, Clínica São Luckas, Avenida Expedicionários Brasileiros, 232, Vila Brasileira, I 3256400 - Itatiba, SP, Brazil, Tel (II) 45242I32,Email karlafabiana.tribomed@gmail.com

Received: October 30, 2017 | Published: December 20, 2017

\section{Introduction}

The cancer corresponds to a group of several diseases that have in common the uncontrolled proliferation of abnormal cells, being able to appear in any age and place of the organism. It is a disease whose incidence has grown every year around the world, and in Brazil, according to INCA data, in 2016, there were 420.310 new cases of cancer, of these, $3 \%$ were pediatric tumors. This means that there is an expectation that by 2017 approximately 12.600 new cases of cancer will be diagnosed in children and adolescents.

Adolescence is a delicate stage of development, marked by the acquisition of body image and the structuring of personality. This period is complicated when this adolescent is affected by cancer and is in palliative care. Assistance to this adolescent is a challenge for both the family and the care team, involving their autonomy, bonds, affections and the specifics that mark this stage of human development. Illness leads to the breakdown of these links and the commitment of autonomy, due to the routines altered by the treatment and hospitalizations. These changes invariably lead to frequent teenage crises, which should not be seen as undesirable disorders, but rather as phenomena necessary for trial and error, for the search for a new sense of personality and its social role.

In this transition, the overprotection of parents, family and friends interfere in the construction of the subjectivity between the Self and the Other, in the search for new meanings for the Self. The body image in adolescence is also the core of identity of the Self, with psychosocial repercussions during this period of physical changes and in daily life of adolescent. However, for the adolescent affected by an illness, this identity is already corrupted by invasive procedures, surgeries and possible concrete annihilations of the body. ${ }^{1}$

When cure ceases to be the central treatment option, patient, family and the team face major challenges, such as establishing measures to control pain and other symptoms, psychosocial support and the possible maintenance of social bonds, and care goes beyond cure. ${ }^{2}$ An appeal is proposed by the World Health Organization (WHO) in 1998, which established a definition for palliative care in children: a therapeutic modality that aims at care provided to child (body, mind and spirit), valuing the quality of life patient and their families.

The camp in palliative care of young people is a modality of care that has been implemented in a discreet and gradual way in the health area. The great purpose is encourage these people, strengthen hope and rescue the self-confidence of those who are undergoing a diagnosis without therapeutic possibilities of healing, allowing children to leave the excessively protected environment and contact people who are in different stages of illness and treatment. The exchange of experiences that occurs in camps is able to replenish the patient's forces to cope with disease and thus directly influence the success of treatment. ${ }^{3}$

\section{Objectives}

The experience of the camp was promoted with the objective of developing an efficient empowerment resource to strengthen the autonomy and self-confidence of adolescents and children diagnosed with cancer and/or palliative care, promoting health through the restoration of the human capacity to act based on choices.

\section{Materials and methods}

Qualitative descriptive study, exploratory in nature. Thirty adolescents and children diagnosed with cancer and in treatment, being one adolescent in palliative care, attended the outpatient clinic of a large philanthropic hospital, a reference in the treatment of cancer, located in the city of São Paulo; and 29 companions. Participation was made through the enrollment in the hospital of patients and accompanying persons (siblings) interested in participating and who counted on the consent of those responsible. The camp took place for the third consecutive year, during 03 days of April 2013, in a campground near the city of São Paulo, with a team of 1 physician, 3 
nurses, 2 psychologists and 2 teachers, as well as the recreation team provided by the camp.

\section{Results}

The observations showed that the camp made it possible to transpose the limitations imposed by the disease, rescuing its potentialities and strengthening its autonomy and self-perception. The group experienced the capacity to be involved, to affect and to be affected by the other, enriching the dimension of alterity, respect and autonomy.

\section{Discussion}

The process of cancer sickness brings to the adolescent a series of losses that accumulate the infantile losses expressed in three fundamental griefs: the lost infant body, the role and infantile identity and the parents of childhood. ${ }^{1}$ The confrontation with death during adolescence can lead to greater conflicts despite what is already experienced during development phase. Haagedoorn $\mathrm{EML}^{4}$ developed a study in which the need to rethink this adolescent confrontation with death was emphasized, with emphasis on health care. In this context, ${ }^{5}$ concluded that strengthening the adolescent's cognitive development makes him/her understand the inevitability of death, despite the feeling of omnipotence that takes over adolescence.

One of the treatments that can help minimize the psychic and emotional consequences of cancer, both in patients and their families, is psychological care. This kind of care requires a lot of attention and sensitivity from the professionals involved in order to make this time of their lives least suffered. Based on this thought, our study helped patients understand about their illness, but above all, it allowed them to face this obstacle by learning from experience of collective.

With a strategy similar to that presented in this study, the children and adolescents treated at $\mathrm{AC}$ Camargo, ${ }^{3}$ an integrated center for diagnosis, treatment, teaching and research of cancer, organized to their patients since the $1980 \mathrm{~s}, 8$ therapeutic camps. This is because they believe there is a direct effect on the quality of life of these patients, allowing the release of overprotection imposed by the hospital and family, socialization with other patients at different stages of treatment, ensuring the exchange of experiences, recreation and fun for resupply of forces in order to continue treatment and finally, allows the approach with the team outside the hospital environment. ${ }^{6,7}$

\section{Conclusion}

The interdependence between knowledge towards a life and death with quality evidenced the importance of this activity as a means to share treatment experiences and sensations of support and care outside the family and hospital environment. This experience also showed the importance of adolescents empowerment for quality of life, showing that camp is an efficient resource to be worked with adolescents in palliative care, helping in the perception of individuality, autonomy and formation of bonds.

\section{Acknowledgements}

None.

\section{Conflict of interest}

The author declares no conflict of interest.

\section{References}

1. Carbonari Karla, Seabra Carolina Ribeiro. Psico-oncologia: assistência humanizada e qualidade de vida. São Paulo, Brazil: Springer; 2013.

2. Conselho regional de medicina do estado de são paulo. Cuidado paliativo. CREMESP, São Paulo, Brazil: Springer; 2008. 689 p.

3. AC Camargo. Oncologia pediátrica: a importância do acolhimento e humanização; 2017.

4. Haagedoorn EML, Oldhoff J, Bender W, et al. Essential oncology for helth professionals. Netherlands: Van Gorcum; 1994. 450 p.

5. Linebarger JS, Sahler OJ, Egan KA. Coping with death. Pediatrics in Review. 1970;30:350-356.

6. Lewin K. Problemas de dinâmica dos grupos; 1970.

7. www.inca.gov.br/estimativa/2016/sintese-de-resultados-comentarios. asp. 